Published in final edited form as:

Curr Opin Nephrol Hypertens. 2017 March ; 26(2): 67-73. doi:10.1097/MNH.0000000000000297.

\title{
Role of corin in the regulation of blood pressure
}

\author{
Hui Lia, Yue Zhang ${ }^{\mathrm{a}}$, and Qingyu Wu $\mathbf{u}^{\mathrm{a}, \mathrm{b}}$ \\ ${ }^{a}$ Cyrus Tang Hematology Center, MOE Engineering Center of Hematological Disease, and \\ Collaborative Innovation Center of Hematology, Soochow University, Suzhou, China \\ bMolecular Cardiology, Cleveland Clinic, Cleveland, Ohio, USA
}

\begin{abstract}
Purpose of review-Corin is a transmembrane protease that activates atrial natriuretic peptide (ANP), an important hormone in regulating salt-water balance and blood pressure. This review focuses on the regulation of corin function and potential roles of corin defects in hypertensive, heart, and renal diseases.
\end{abstract}

Recent findings-Proprotein convertase subtilisin/kexin- 6 has been identified as a primary enzyme that converts zymogen corin to an active protease. Genetic variants that impair corin intracellular trafficking, cell surface expression, and zymogen activation have been found in patients with hypertension, cardiac hypertrophy, and pre-eclampsia. Reduced corin expression has been detected in animal models of cardiomyopathies and in human failing hearts. Low levels of circulating soluble corin have been reported in patients with heart disease and stroke. Corin, ANP and natriuretic peptide receptor-A mRNAs, and proteins have been colocalized in human renal segments, suggesting a corin-ANP autocrine function in the kidney.

Summary-Corin is a key enzyme in the natriuretic peptide system. The latest findings indicate that corin-mediated ANP production may act in a tissue-specific manner to regulate cardiovascular and renal function. Corin defects may contribute to major diseases such as hypertension, heart failure, pre-eclampsia, and kidney disease

\section{Keywords}

atrial natriuretic peptide; corin; hypertension; proprotein convertase subtilisin/kexin-6; sodium homeostasis

\section{INTRODUCTION}

The heart acts as a central pump in the circulatory system. The discovery of atrial natriuretic peptide (ANP), also called atrial natriuretic factor, in the 1980s revealed another heart function in maintaining cardiovascular homeostasis [1]. Upon sensing increased blood volume, cardiomyocytes release ANP as a natriuretic hormone to promote renal sodium

Correspondence to Dr Qingyu Wu, Professor, Department of Molecular Cardiology, Cleveland Clinic, 9500 Euclid Avenue, Cleveland, OH 44195, USA.. Tel: +1 216444 4351; wuq@ccf.org.

Conflicts of interest

There are no conflicts of interest. 
excretion and relaxes peripheral vessels. This cardiac endocrine function is important for sodium homeostasis and normal blood pressure [2,3]. Latest studies show that ANP is also involved in energy metabolism and cardiovascular responses to stress and inflammation [4ロ, $5-7]$.

Most peptide hormones are produced as prohormones, which are converted to mature forms by proteolytic cleavage. Such post-translational processing also is required for ANP generation. ANP is synthesized as prepro-ANP, consisting of a signal peptide, a propeptide, and a C-terminal mature peptide [8,9]. The signal peptide is removed by signal peptidase in the endoplasmic reticulum (ER) to yield pro-ANP that is stored in the dense granules. Upon secretion, pro-ANP is converted to mature ANP on the cell surface [10]. The enzyme responsible for pro-ANP processing was a target of intense investigation [11-14], but remained elusive for more than two decades before corin was discovered.

\section{CORIN: A TRANSMEMBRANE SERINE PROTEASE}

Corin was identified as a serine protease from human hearts [15]. It consists of 1042 amino acids and includes an N-terminal cytoplasmic tail, a trans-membrane domain, and an extracellular region with two frizzled domains, eight low-density lipoprotein (LDL) receptor repeats, a scavenger receptor domain, and a C-terminal protease domain (Fig. 1). Such an arrangement of diverse domain structures is unique among proteases. Corin is the only serine protease containing frizzled-like domains [16]. Between the scavenger receptor domain and the protease domain is an activation site (Fig. 1). Cleavage at this site converts zymogen corin to an active enzyme. Human corin has $19 \mathrm{~N}$-glycosylation sites and is heavily glycosylated [17]. Alternatively spliced mRNAs may exist to encode corin isoforms with different cytoplasmic sequences [18].

The signature catalytic residues and substrate-binding pocket in the protease domain predict corin to be a trypsin-like protease [15]. As a transmembrane protease highly expressed in cardiomyocytes, corin is expected to cleave proteins or peptides in the heart. Indeed, biochemical studies showed that corin activated pro-ANP in a sequence-specific manner [19]. Blocking corin expression inhibited pro-ANP processing in cardiomyocytes [20]. In corin knockout mice, mature ANP was undetectable [21], and the mice had salt-sensitive hypertension and cardiac hypertrophy [21,22]. These results show that corin is the longsought physiological pro-ANP convertase that is essential for normal blood pressure.

Corin also cleaves pro-brain natriuretic peptide (pro-BNP) in vitro [23,24]. In corin knockout mice, however, pro-BNP processing was not abolished [25 $\mathbf{\square}$ ], indicating that corin-mediated pro-BNP cleavage is not essential in vivo. Furin is another pro-BNP processing enzyme $[23,24]$, which may act as a primary pro-BNP convertase in vivo [26]]. Potential role of corin in activating pro-C-type natriuretic peptide (pro-CNP) has been examined in cell-based studies. The results indicate that furin, but not corin, is a primary pro-CNP convertase [27]. It remains unknown if corin has other physiological substrates, especially in tissues such as skin, brain, and chondrocytes in which corin is expressed. 


\section{REGULATION OF CORIN EXPRESSION AND ACTIVITY}

Proper regulation of protease activities is important in many physiological processes. Recent studies have shown that corin expression and activity can be regulated at different levels from gene transcription, intracellular trafficking, cell surface expression to post-translational modifications (Fig. 2), which are discussed in the following sections.

\section{Transcription and mRNA stability}

Corin is expressed most abundantly in the atrium [15,28]. GATA-4 is a major transcription factor that controls corin expression in cardiomyocytes [29] (Fig. 2). Under pathological conditions such as heart failure [30-32], diabetic cardiomyopathy [33 ], and radiationinduced heart injury [34], corin expression and/or activity may be reduced. In heart failure patients, unprocessed natriuretic peptides are abundant in their blood, an indication of limited corin activity in falling hearts. Inositol-requiring enzyme 1 (IRE1) is an ER-stress protein with an endoribonuclease activity. A recent study indicated that increased IRE1 expression in falling hearts may enhance corin mRNA degradation, thereby contributing to corin deficiency [35].

\section{Zymogen activation}

Corin is synthesized as a zymogen. Proprotein convertase subtilisin/kexin-6 (PCSK6) has been identified as a primary corin activator [25 $\mathbf{D}$ ]. In cells, PCSK6 and corin travel separately to the cell surface, wherein PCSK6 cleaves corin at the conserved activation site, converting zymogen corin to an active enzyme (Fig. 2). Blocking PCSK6 expression by small interfering RNAs (siRNAs) inhibits corin activation in cultured cells. PCSK6 knockout mice have no detectable corin activity in the heart and develop salt-sensitive hypertension [25 $\mathbf{m}$ ]. These results indicate a key role of PCSK6 in regulating corin activity and blood pressure. Among PCSK proteases, PCSK9 is involved in LDL receptor degradation [36]. PCSK9 inhibitors are used to treat patientswith high LDL cholesterol levels [37]. Thus, proteases of the PCSK family may play different roles in cardiovascular biology.

\section{Cell surface targeting}

Cell surface expression is essential for corin activation and function. Cytoplasmic sequences regulate corin intracellular trafficking and cell surface targeting [18,38,39]. $N$-glycosylation is also important for the intracellular trafficking of corin. Blocking $\mathrm{N}$-glycosylation by tunicamycin inhibits corin surface expression and zymogen activation in cultured cardiomyocytes [17,40]. $\mathrm{N}$-glycosylation at Asn-697 in the scavenger receptor domain and Asn-1022 in the protease domain have been shown to promote corin cell surface expression [41]. It remains unknown how $\mathrm{N}$-glycans facilitate the trafficking of corin inside the cell.

\section{Ectodomain shedding}

Uncontrolled proteolytic activities can be detrimental. As a protection mechanism, many proteases are coevolved with their cognate inhibitors. Remarkably, corin remains active in the presence of human plasma [42], indicating that circulating protease inhibitors do not block corin activity. To date, no physiological corin inhibitors have been identified. How is 
its activity controlled once corin is activated on the cell surface? In cultured cardiomyocytes, activated corin undergoes autocleavage and metalloproteinase-mediated shedding, which reduces corin protein and activity on the cell surface [43] (Fig. 2). These proteolytic events may serve as a regulatory mechanism to prevent excessive corin activity in the heart.

\section{HUMAN CORIN VARIANTS IN HYPERTENSIVE DISEASES}

ANP variants are associated withblood pressure levels and heart disease [6,44,45]. To date, corin variants have been reported in patients with hypertension and heart disease. Dries et al. [46] identified a corin variant allele (T555I and Q568P) in African Americans, which was associated with hypertension, cardiac hypertrophy, and reduced natriuretic peptide processing [47,48]. The T555I and Q568P substitutions are in the frizzled-2 domain (Fig. 3) and impair corin activation and function in vitro [25 $\mathbf{m}, 49]$. Transgenic mice expressing this variant allele had high levels of pro-ANP in the heart and developed salt-sensitive hypertension and cardiac hypertrophy [50]. These results indicate that the corin variant, which occurs in $\sim 10 \%$ of African Americans, is defective in vivo and may contribute to cardiovascular disease in this high-risk population.

R539C is another corin variant identified in a hypertensive family [51] (Fig. 3). The amino acid change creates a mismatched disulfide bond that alters the frizzled- 2 domain conformation and causes corin autocleavage and inactivation [51]. Zhang et al. [39] also reported an insertion variant, c.102_103insA, which occurs preferentially in hypertensive patients in China (Fig. 3). The insertion shortens the corin cytoplasmic tail and reduces corin trafficking in the Golgi and cell surface expression [39]. These results indicate that genetic variants that impair corin structure and function may contribute to hypertension and heart disease in general populations.

Pre-eclampsia is a major disease characterized by gestational hypertension and proteinuria. Reduced uteroplacental perfusion and placental hypoxia play a central role in the disease [52,53]. Corin expression was detected in human and mouse pregnant uteruses, suggesting a local corin function [54,55]. Pregnant corin and ANP knockout mice were found to have delayed trophoblast invasion and poorly remodeled uterine spiral arteries [54]. The mice developed gestational hypertension and proteinuria [54,56], a phenotype similar to that in pre-eclamptic women. These findings suggest that locally activated ANP by corin in the uterus may promote spiral artery remodeling and that defects in the uterine corin function may cause pre-eclampsia.

To date, two intronic single nucleotide polymorphisms (SNPs) in the corin gene have been identified that are associated with pre-eclampsia in Caucasian women [57]. These SNPs are located next to exon 9 that encodes the LDL receptor-4 repeat and may alter mRNA splicing [57]. Cui et al. [54] also found two corin mutations in pre-eclamptic women: K317E in LDL receptor-2 repeat and S472G in the frizzled-2 domain (Fig. 3). In functional studies, the K317E mutation was found to alter LDL receptor-2 conformation, impairing corin activation by PCSK6, whereas the S472G mutation was found to abolish a $\beta$-sheet in the frizzled-2 domain, causing protein misfolding and ER retention [58]. These results indicate that 
naturally occurring variants may impair corin function by affecting gene expression, protein folding, intracellular trafficking, and post-translational modifications.

\section{PLASMA SOLUBLE CORIN IN HEART DISEASE AND STROKE}

Soluble corin has been detected in human blood, indicating that corin fragments cleaved in tissues may enter into the circulation [59,60]. Decreased circulating corin levels have been reported in patients with cardiovascular diseases, including acute myocardial infarction (AMI) $[61,62 \square, 63 \square]$, coronary artery disease $[64,65]$, heart failure $[66,67,68 \boldsymbol{\square}]$, and stroke [69] (Table 1). In heart disease patients, reduced circulating corin levels often correlated with poor clinical outcomes, suggesting that corin deficiency may be an underlying contributing factor. Consistent with this hypothesis, reduced cardiac corin expression was found in animal models of dilated and diabetic cardiomyopathies [33 $\mathbf{\square}, 70 \mathbf{\square}]$. Conversely, overexpression of corin improved cardiac function and survival in a mouse model of dilated cardiomyopathy [71].

Hypertension is a major risk factor for stroke. ANP variant rs5063 is associated with a high risk for stroke [72]. Compared with healthy controls, stroke patients were found to have lower serum corin levels [69] (Table 1). In men and women, individuals with the lowest quartile corin levels had threefold to five-fold and 8.5-17.5-fold higher risks, respectively, of ischemic and hemorrhagic stroke, compared with individuals with corin levels in the top quartile [69]. Low levels of serum corin were also associated with a high risk for major disability within 3 months after stroke [73]. Given the role of corin in regulating blood pressure, these new findings should encourage further investigations to understand the potential role of corin in stroke [74].

In addition to heart disease and stroke, altered circulating corin levels have been linked to other diseases. In a population study involving 2498 adults of more than 30 years old, increased serum corin levels were associated with hypertension [75], obesity [76], dyslipidemia [77], and hyperglycemia [78]. High levels of plasma corin were found in patients with atrial fibrillation [79]. In pregnant women, increased plasma corin levels were associated with gestational age and hypertension [54,80-82]. Khalil et al. [80] reported that plasma corin levels before 20 weeks of gestation were lower in one-third of pre-eclamptic women compared with normotensive controls, suggesting that reduced plasma corin may be a predictor for pre-eclampsia. At this time, the tissue-origin and activity of the circulating corin remain unclear, making it difficult to interpret the data. Recently, Yin et al. [83] developed an electrochemical assay that measures corin activity in human plasma. Studies with such an activity assay may help to understand the significance of the circulating corin in disease settings.

\section{RENAL CORIN EXPRESSION AND FUNCTION}

Corin was discovered as a cardiac protease [15]. Later studies detected corin expression in noncardiac tissues such as uterus, skin, and brain [54,55,84-86]. Corin is also expressed in mouse, rat, and human kidneys [15,87-89]. In rat models of kidney disease, reduced renal corin expression was reported [89]. Similar results of low renal and urinary corin levels were 
found in patients with chronic kidney disease [87]. These data suggest a potential role of corin in kidney biology and disease.

Recently, Dong et al. [90] ] reported colocalization of corin, ANP and natriuretic peptide receptor-A mRNA, and protein expression in human renal segments. The highest expression levels were in the proximal convoluted tubules and the inner medullary connecting ducts. These results indicate that corin may produce ANP in the renal segments as an autocrine mechanism to regulate sodium reabsorption [90 $]$ ]. These results also point to the proximal convoluted tubule as a major ANP action site. ANP-mediated natriuretic response has been well established as a cardiac endocrine function [91]. The latest findings of corin and ANP coexpression in renal segments suggest that a corin-ANP autocrine function may exist in the kidney to regulate sodium homeostasis.

Sodium retention is common in kidney disease [92]. In rat kidney disease models, reduced renal corin expression contributed to sodium retention [89], indicating that an impaired corin-ANP autocrine function may be an underlying mechanism. The question remains how the renal corin-ANP autocrine function differs from the cardiac corin-ANP endocrine function in regulating sodium homeostasis. In nephrotic patients, sodium and water retention often occurs despite high levels of plasma ANP $[93,94]$. Is it possible that these patients have an impaired renal corin-ANP autocrine function that is not compensated by circulating ANP of the heart origin? Additional studies will be important to understand the role of corin in renal physiology and disease.

\section{CONCLUSION}

Corin is a type II transmembrane serine protease that converts pro-ANP to ANP, thereby regulating sodium homeostasis and blood pressure. Corin variants that impair corin function have been reported in patients with hypertension, heart disease, pre-eclampsia, and kidney disease. In addition to the heart, corin is expressed in non-cardiac tissues. The latest studies indicate that corin and ANP may act in a tissue-specific manner to regulate salt-water balance and cardiovascular homeostasis.

\section{Acknowledgments}

The authors thank Dr Ningzheng Dong and other laboratory members for their helpful discussions.

Financial support and sponsorship

This work was supported in part by grants from the National Institutes of Health (HD064634 and HL126697) and the Priority Academic Program Development of Jiangsu Higher Education Institutions in China.

\section{REFERENCES AND RECOMMENDED READING}

Papers of particular interest, published within the annual period of review, have been highlighted as:

- of special interest

[ of outstanding interest 
1. de Bold AJ. Atrial natriuretic factor: a hormone produced by the heart. Science. 1985; 230:767-770. [PubMed: 2932797]

2. Armaly Z, Assady S, Abassi Z. Corin: a new player in the regulation of saltwater balance and blood pressure. Curr Opin Nephrol Hypertens. 2013; 22:713-722. [PubMed: 24100222]

3. Theilig F, Wu Q. ANP-induced signaling cascade and its implications in renal pathophysiology. Am J Physiol Renal Physiol. 2015; 308:F1047-F1055. [PubMed: 25651559]

4. Chen W, Spitzl A, Mathes D, et al. Endothelial actions of ANP enhance myocardial inflammatory infiltration in the early phase after acute infarction. Circ Res. 2016; 119:237-248. [PubMed: 27142162] This study reveals an unexpected role of ANP in increasing endothelial permeability and promoting neutrophil infiltration in the early phase of AMI.

5. Schlueter N, de Sterke A, Willmes DM, et al. Metabolic actions of natriuretic peptides and therapeutic potential in the metabolic syndrome. Pharmacol Ther. 2014; 144:12-27. [PubMed: 24780848]

6. Song W, Wang H, Wu Q. Atrial natriuretic peptide in cardiovascular biology and disease (NPPA). Gene. 2015; 569:1-6. [PubMed: 26074089]

7. Zois NE, Bartels ED, Hunter I, et al. Natriuretic peptides in cardiometabolic regulation and disease. Nat Rev Cardiol. 2014; 11:403-412. [PubMed: 24820868]

8. Oikawa S, Imai M, Ueno A, et al. Cloning and sequence analysis of cDNA encoding a precursor for human atrial natriuretic polypeptide. Nature. 1984; 309:724-726. [PubMed: 6203042]

9. Seidman CE, Duby AD, Choi E, et al. The structure of rat preproatrial natriuretic factor as defined by a complementary DNA clone. Science. 1984; 225:324-326. [PubMed: 6234658]

10. Sei CA, Hand GL, Murray SF, Glembotski CC. The cosecretional maturation of atrial natriuretic factor by primary atrial myocytes. Mol Endocrinol. 1992; 6:309-319. [PubMed: 1533896]

11. Imada T, Takayanagi R, Inagami T. Atrioactivase, a specific peptidase in bovine atria for the processing of pro-atrial natriuretic factor. Purification and characterization. J Biol Chem. 1988; 263:9515-9519. [PubMed: 2967825]

12. Michener ML, Gierse JK, Seetharam R, et al. Proteolytic processing of atriopeptin prohormone. Mol Pharmacol. 1986; 30:552-557. [PubMed: 2946928]

13. Seidah NG, Cromlish JA, Hamelin J, et al. Homologous IRCM-serine protease 1 from pituitary, heart atrium and ventricle: a common pro-hormone maturation enzyme? Biosci Rep. 1986; 6:835844. [PubMed: 3028526]

14. Wypij DM, Harris RB. Atrial granules contain an amino-terminal processing enzyme of atrial natriuretic factor. J Biol Chem. 1988; 263:7079-7086. [PubMed: 2966800]

15. Yan W, Sheng N, Seto M, et al. Corin, a mosaic transmembrane serine protease encoded by a novel cDNA from human heart. J Biol Chem. 1999; 274:14926-14935. [PubMed: 10329693]

16. Yan J, Jia H, Ma Z, et al. The evolutionary analysis reveals domain fusion of proteins with frizzledlike CRD domain. Gene. 2014; 533:229-239. [PubMed: 24135643]

17. Liao X, Wang W, Chen S, Wu Q. Role of glycosylation in corin zymogen activation. J Biol Chem. 2007; 282:27728-27735. [PubMed: 17660514]

18. Qi X, Jiang J, Zhu M, Wu Q. Human corin isoforms with different cytoplasmic tails that alter cell surface targeting. J Biol Chem. 2011; 286:20963-20969. [PubMed: 21518754]

19. Yan W, Wu F, Morser J, Wu Q. Corin, a transmembrane cardiac serine protease, acts as a pro-atrial natriuretic peptide-converting enzyme. Proc Natl Acad Sci USA. 2000; 97:8525-8529. [PubMed: 10880574]

20. Wu F, Yan W, Pan J, et al. Processing of pro-atrial natriuretic peptide by corin in cardiac myocytes. J Biol Chem. 2002; 277:16900-16905. [PubMed: 11884416]

21. Chan JC, Knudson O, Wu F, et al. Hypertension in mice lacking the proatrial natriuretic peptide convertase corin. Proc Natl Acad Sci U S A. 2005; 102:785-790. [PubMed: 15637153]

22. Wang W, Shen J, Cui Y, et al. Impaired sodium excretion and salt-sensitive hypertension in corindeficient mice. Kidney Int. 2012; 82:26-33. [PubMed: 22418978]

23. Ichiki T, Huntley BK, Burnett JC Jr. BNP molecular forms and processing by the cardiac serine protease corin. Adv Clin Chem. 2013; 61:1-31. [PubMed: 24015598] 
24. Semenov AG, Seferian KR. Biochemistry of the human B-type natriuretic peptide precursor and molecular aspects of its processing. Clin Chim Acta. 2011; 412:850-860. [PubMed: 21396929]

25. Chen S, Cao P, Dong N, et al. PCSK6-mediated corin activation is essential for normal blood pressure. Nat Med. 2015; 21:1048-1053. [PubMed: 26259032] This study identifies PCSK6 as the physiological corin activator that is important for sodium homeostasis and normal blood pressure. This study also showed that pro-BNP processing was not abolished in corin and PCSK6 knockout mice.

26. Nishikimi T, Nakagawa Y, Minamino N, et al. Pro-B-type natriuretic peptide is cleaved intracellularly: impact of distance between O-glycosylation and cleavage sites. Am J Physiol Regul Integr Comp Physiol. 2015; 309:R639-R649. [PubMed: 26136529] This study analyzed pro-BNP processing in rat atrial and ventricular myocytes and showed that furin was the primary protease for pro-BNP processing.

27. Wu C, Wu F, Pan J, et al. Furin-mediated processing of pro-C-type natriuretic peptide. J Biol Chem. 2003; 278:25847-25852. [PubMed: 12736257]

28. Hooper JD, Scarman AL, Clarke BE, et al. Localization of the mosaic transmembrane serine protease corin to heart myocytes. Eur J Biochem. 2000; 267:6931-6937. [PubMed: 11082206]

29. Pan J, Hinzmann B, Yan W, et al. Genomic structures of the human and murine corin genes and functional GATA elements in their promoters. J Biol Chem. 2002; 277:38390-38398. [PubMed: 12154094]

30. Chen S, Sen S, Young D, et al. Protease corin expression and activity in failing hearts. Am J Physiol Heart Circ Physiol. 2010; 299:H1687-H1692. [PubMed: 20802129]

31. Ichiki T, Boerrigter G, Huntley BK, et al. Differential expression of the pronatriuretic peptide convertases corin and furin in experimental heart failure and atrial fibrosis. Am J Physiol Regul Integr Comp Physiol. 2013; 304:R102-R109. [PubMed: 23152112]

32. Langenickel TH, Pagel I, Buttgereit J, et al. Rat corin gene: molecular cloning and reduced expression in experimental heart failure. Am J Physiol Heart Circ Physiol. 2004; 287:H1516H1521. [PubMed: 15155264]

33. Pang A, Hu Y, Zhou P, et al. Corin is down-regulated and exerts cardioprotective action via activating pro-atrial natriuretic peptide pathway in diabetic cardiomyopathy. Cardiovasc Diabetol. 2015; 14:134. [PubMed: 26446774] This study reports that corin expression was reduced in a rat model of diabetic cardiomyopathy and that corin deficiency contributed to endothelial dysfunction and impaired vascular remodeling.

34. Kim EJ, Lee J, Jung YR, et al. Involvement of corin downregulation in ionizing radiation-induced senescence of myocardial cells. Int J Mol Med. 2015; 35:731-738. [PubMed: 25543718]

35. Lee R, Xu B, Rame JE, et al. Regulated inositol-requiring protein 1-dependent decay as a mechanism of corin RNA and protein deficiency in advanced human systolic heart failure. $\mathrm{J}$ Am Heart Assoc. 2014; 3:e001104. [PubMed: 25516437]

36. Seidah NG, Awan Z, Chretien M, Mbikay M. PCSK9: a key modulator of cardiovascular health. Circ Res. 2014; 114:1022-1036. [PubMed: 24625727]

37. Burke AC, Dron JS, Hegele RA, Huff MW. PCSK9: regulation and target for drug development for dyslipidemia. Annu Rev Pharmacol Toxicol. 2016 [Epub ahead of print].

38. Li H, Zhang Y, Wang L, et al. A novel cytoplasmic tail motif regulates mouse corin expression on the cell surface. Biochem Biophys Res Commun. 2015; 465:152-158. [PubMed: 26241673]

39. Zhang Y, Li H, Zhou J, et al. A corin variant identified in hypertensive patients that alters cytoplasmic tail and reduces cell surface expression and activity. Sci Rep. 2014; 4:7378. [PubMed: 25488193]

40. Gladysheva IP, King SM, Houng AK. N-glycosylation modulates the cell-surface expression and catalytic activity of corin. Biochem Biophys Res Commun. 2008; 373:130-135. [PubMed: 18549807]

41. Wang H, Zhou T, Peng J, et al. Distinct roles of N-glycosylation at different sites of corin in cell membrane targeting and ectodomain shedding. J Biol Chem. 2015; 290:1654-1663. [PubMed: 25451932] 
42. Knappe S, Wu F, Masikat MR, et al. Functional analysis of the transmembrane domain and activation cleavage of human corin: design and characterization of a soluble corin. J Biol Chem. 2003; 278:52363-52370. [PubMed: 14559895]

43. Jiang J, Wu S, Wang W, et al. Ectodomain shedding and autocleavage of the cardiac membrane protease corin. J Biol Chem. 2011; 286:10066-10072. [PubMed: 21288900]

44. Hu BC, Li Y, Liu M, et al. Blood pressure and urinary sodium excretion in relation to 16 genetic polymorphisms in the natriuretic peptide system in Chinese. Endocr J. 2014; 61:861-874. [PubMed: 24954621]

45. Rubattu S, Sciarretta S, Volpe M. Atrial natriuretic peptide gene variants and circulating levels: implications in cardiovascular diseases. Clin Sci (Lond). 2014; 127:1-13. [PubMed: 24611929]

46. Dries DL, Victor RG, Rame JE, et al. Corin gene minor allele defined by 2 missense mutations is common in blacks and associated with high blood pressure and hypertension. Circulation. 2005; 112:2403-2410. [PubMed: 16216958]

47. Rame JE, Drazner MH, Post W, et al. Corin I555(P568) allele is associated with enhanced cardiac hypertrophic response to increased systemic after-load. Hypertension. 2007; 49:857-864. [PubMed: 17296875]

48. Rame JE, Tam SW, McNamara D, et al. Dysfunctional corin I555(P568) allele is associated with impaired brain natriuretic peptide processing and adverse outcomes in blacks with systolic heart failure: results from the Genetic Risk Assessment in Heart Failure substudy. Circ Heart Fail. 2009; 2:541-548. [PubMed: 19919978]

49. Wang W, Liao X, Fukuda K, et al. Corin variant associated with hypertension and cardiac hypertrophy exhibits impaired zymogen activation and natriuretic peptide processing activity. Circ Res. 2008; 103:502-508. [PubMed: 18669922]

50. Wang W, Cui Y, Shen J, et al. Salt-sensitive hypertension and cardiac hypertrophy in transgenic mice expressing a corin variant identified in blacks. Hypertension. 2012; 60:1352-1358. [PubMed: 22987923]

51. Dong N, Fang C, Jiang Y, et al. Corin mutation R539C from hypertensive patients impairs zymogen activation and generates an inactive alternative ectodomain fragment. J Biol Chem. 2013; 288:7867-7874. [PubMed: 23372161]

52. Chaiworapongsa T, Chaemsaithong P, Yeo L, Romero R. Pre-eclampsia part 1: current understanding of its pathophysiology. Nat Rev Nephrol. 2014; 10:466-480. [PubMed: 25003615]

53. Redman CW, Sargent IL. Latest advances in understanding preeclampsia. Science. 2005; 308:1592-1594. [PubMed: 15947178]

54. Cui Y, Wang W, Dong N, et al. Role of corin in trophoblast invasion and uterine spiral artery remodelling in pregnancy. Nature. 2012; 484:246-250. [PubMed: 22437503]

55. Kaitu'u-Lino TJ, Ye L, Tuohey L, et al. Corin, an enzyme with a putative role in spiral artery remodeling, is up-regulated in late secretory endometrium and first trimester decidua. Hum Reprod. 2013; 28:1172-1180. [PubMed: 23434834]

56. Armstrong DW, Tse MY, O'Tierney-Ginn PF, et al. Gestational hypertension in atrial natriuretic peptide knockout mice and the developmental origins of salt-sensitivity and cardiac hypertrophy. Regul Pept. 2013; 186:108-115. [PubMed: 23981445]

57. Stepanian A, Alcais A, de Prost D, et al. Highly significant association between two common single nucleotide polymorphisms in CORIN gene and preeclampsia in Caucasian women. PLoS One. 2014; 9:e113176. [PubMed: 25474356]

58. Dong N, Zhou T, Zhang Y, et al. Corin mutations K317E and S472G from preeclamptic patients alter zymogen activation and cell surface targeting. J Biol Chem. 2014; 289:17909-17916. [PubMed: 24828501]

59. Dong N, Chen S, Wang W, et al. Corin in clinical laboratory diagnostics. Clin Chim Acta. 2012; 413:378-383. [PubMed: 22093942]

60. Peleg A, Jaffe AS, Hasin Y. Enzyme-linked immunoabsorbent assay for detection of human serine protease corin in blood. Clin Chim Acta. 2009; 409:85-89. [PubMed: 19751717]

61. Feistritzer HJ, Klug G, Reinstadler SJ, et al. Circulating corin concentrations are related to infarct size in patients after ST-segment elevation myocardial infarction. Int J Cardiol. 2015; 192:22-23. [PubMed: 25981578] 
62. Zhang SM, Shen JX, Li H, et al. Association between serum corin levels and risk of acute myocardial infarction. Clin Chim Acta. 2016; 452:134-137. [PubMed: 26577631] This study reports that serum corin levels were decreased in patients with AMI and that the reduction inversely correlated with the incidences of ST elevation and non-ST elevation MI.

63. Zhou X, Chen J, Zhang Q, et al. Prognostic value of plasma soluble corin in patients with acute myocardial infarction. J Am Coll Cardiol. 2016; 67:2008-2014. [PubMed: 27126527] In this prospective study, low levels of plasma corin were found to be a significant predictor of major adverse cardiac events in patients with AMI.

64. Barnet CS, Liu X, Body SC, et al. Plasma corin decreases after coronary artery bypass graft surgery and is associated with postoperative heart failure: a pilot study. J Cardiothorac Vasc Anesth. 2015; 29:374-381. [PubMed: 25649697]

65. Peleg A, Ghanim D, Vered S, Hasin Y. Serum corin is reduced and predicts adverse outcome in non-ST-elevation acute coronary syndrome. Eur Heart Acute Cardiovasc Care. 2013; 2:159-165.

66. Dong N, Chen S, Yang J, et al. Plasma soluble corin in patients with heart failure. Circ Heart Fail. 2010; 3:207-211. [PubMed: 20061521]

67. Ibebuogu UN, Gladysheva IP, Houng AK, Reed GL. Decompensated heart failure is associated with reduced corin levels and decreased cleavage of pro-atrial natriuretic peptide. Circ Heart Fail. 2011; 2011:114-120.

68. Zhou X, Chen JC, Liu Y, et al. Plasma corin as a predictor of cardiovascular events in patients with chronic heart failure. JACC Heart Fail. 2016; 4:664-669. [PubMed: 27179834] In this prospective study, low levels of plasma corin were found to be an independent predictor of major adverse cardiac events in patients with chronic heart failure.

69. Peng H, Zhu F, Shi J, et al. Serum soluble corin is decreased in stroke. Stroke. 2015; 46:17581763. [PubMed: 26022632] This study reports that serum corin levels were reduced in patients with ischemic and hemorrhagic stroke, indicating a potential role of corin deficiency in stroke.

70. Tripathi R, Wang D, Sullivan R, et al. Depressed corin levels indicate early systolic dysfunction before increases of atrial natriuretic peptide/B-type natriuretic peptide and heart failure development. Hypertension. 2016; 67:362-367. [PubMed: 26667411] This report shows that in a mouse model of dilated cardiomyopathy, cardiac corin expression was reduced at an early stage, which contributed to the development of heart failure.

71. Gladysheva IP, Wang D, McNamee RA, et al. Corin overexpression improves cardiac function, heart failure, and survival in mice with dilated cardiomyopathy. Hypertension. 2013; 61:327-332. [PubMed: 23232642]

72. Rubattu S, Ridker P, Stampfer MJ, et al. The gene encoding atrial natriuretic peptide and the risk of human stroke. Circulation. 1999; 100:1722-1726. [PubMed: 10525492]

73. Hu W, Chen S, Song Y, et al. Serum soluble corin deficiency predicts major disability within 3 months after acute stroke. PLoS One. 2016; 11:e0163731. [PubMed: 27658255]

74. Aparicio HJ, Seshadri S. Heart of the matter. Stroke. 2015; 46:1755-1756. [PubMed: 26022635]

75. Peng H, Zhang Q, Cai X, et al. Association between high serum soluble corin and hypertension: a cross-sectional study in a general population of China. Am J Hypertens. 2015; 28:1141-1149. [PubMed: 25663063]

76. Peng H, Zhang Q, Shen H, et al. Association between serum soluble corin and obesity in Chinese adults: a cross-sectional study. Obesity (Silver Spring). 2015; 23:856-861. [PubMed: 25678428]

77. Wang X, Chen S, Zhang Q, et al. Increased serum soluble corin in dyslipidemia: a cross-sectional study. Clin Chim Acta. 2015; 450:310-315. [PubMed: 26344336]

78. Liu Y, Peng H, Zhang Q, et al. Association between serum soluble corin and hyperglycaemia: a cross-sectional study among Chinese adults. BMJ Open. 2015; 5:e009085.

79. Chen F, Xia Y, Liu Y, et al. Increased plasma corin levels in patients with atrial fibrillation. Clin Chim Acta. 2015; 447:79-85. [PubMed: 26048191]

80. Khalil A, Maiz N, Garcia-Mandujano R, et al. Longitudinal changes in maternal corin and midregional proatrial natriuretic peptide in women at risk of preeclampsia. Ultrasound Obstet Gynecol. 2015; 45:190-198. [PubMed: 25296530] 
81. Liu Y, Hu J, Yu Q, et al. Increased serum soluble corin in mid pregnancy is associated with hypertensive disorders of pregnancy. J Womens Health (Larchmt). 2015; 24:572-577. [PubMed: 26086065]

82. Zaki MA, El-Banawy Sel D, El-Gammal HH. Plasma soluble corin and Nterminal pro-atrial natriuretic peptide levels in pregnancy induced hypertension. Pregnancy Hypertens. 2012; 2:4852. [PubMed: 26104990]

83. Yin T, Li H, Zhang Y, et al. Sensitive and low-background electrochemical assay of corin activity via supramolecular recognition and rolling circle amplification. Anal Chim Acta. 2016; 919:2833. [PubMed: 27086096]

84. Enshell-Seijffers D, Lindon C, Morgan BA. The serine protease corin is a novel modifier of the Agouti pathway. Development. 2008; 135:217-225. [PubMed: 18057101]

85. Ghosh D, Ding L, Sivaprasad U, et al. Multiple transcriptome data analysis reveals biologically relevant atopic dermatitis signature genes and pathways. PLoS One. 2015; 10:e0144316. [PubMed: 26717000]

86. Ono Y, Nakatani T, Sakamoto Y, et al. Differences in neurogenic potential in floor plate cells along an anteroposterior location: midbrain dopaminergic neurons originate from mesencephalic floor plate cells. Development. 2007; 134:3213-3225. [PubMed: 17670789]

87. Fang C, Shen L, Dong L, et al. Reduced urinary corin levels in patients with chronic kidney disease. Clin Sci (Lond). 2013; 124:709-717. [PubMed: 23327554]

88. Ichiki T, Huntley BK, Heublein DM, et al. Corin is present in the normal human heart, kidney, and blood, with pro-B-type natriuretic peptide processing in the circulation. Clin Chem. 2011; 57:4047. [PubMed: 21075870]

89. Polzin D, Kaminski HJ, Kastner C, et al. Decreased renal corin expression contributes to sodium retention in proteinuric kidney diseases. Kidney Int. 2010; 78:650-659. [PubMed: 20613715]

90. Dong L, Wang H, Dong N, et al. Localization of corin and atrial natriuretic peptide expression in human renal segments. Clin Sci (Lond). 2016; 130:1655-1664. [PubMed: 27343265] This study shows that corin, ANP, and natriuretic peptide receptor-A are coexpressed in human renal segments, suggesting a corin-ANP autocrine function in the kidney. The study also indicates that the proximal convoluted tubule is a major site of renal ANP action.

91. McGrath MF, de Bold ML, de Bold AJ. The endocrine function of the heart. Trends Endocrinol Metab. 2005; 16:469-477. [PubMed: 16269246]

92. Siddall EC, Radhakrishnan J. The pathophysiology of edema formation in the nephrotic syndrome. Kidney Int. 2012; 82:635-642. [PubMed: 22718186]

93. Humphreys MH. Mechanisms and management of nephrotic edema. Kidney Int. 1994; 45:266281. [PubMed: 8127018]

94. Peterson C, Madsen B, Perlman A, et al. Atrial natriuretic peptide and the renal response to hypervolemia in nephrotic humans. Kidney Int. 1988; 34:825-831. [PubMed: 2974905] 


\section{KEY POINTS}

- Corin is synthesized as a zymogen that is activated by PCSK6 on the cell surface.

- Genetic variants impairing corin intracellular trafficking, cell surface expression, and zymogen activation have been identified in hypertensive patients.

- Low levels of circulating soluble corin have been detected in patients with heart disease and stroke.

- Coexpression of corin, ANP, and natriuretic peptide receptor-A in human renal segments suggests a renal corin-ANP autocrine function that may differ from the cardiac corin-ANP endocrine function in regulating sodium and cardiovascular homeostasis. 


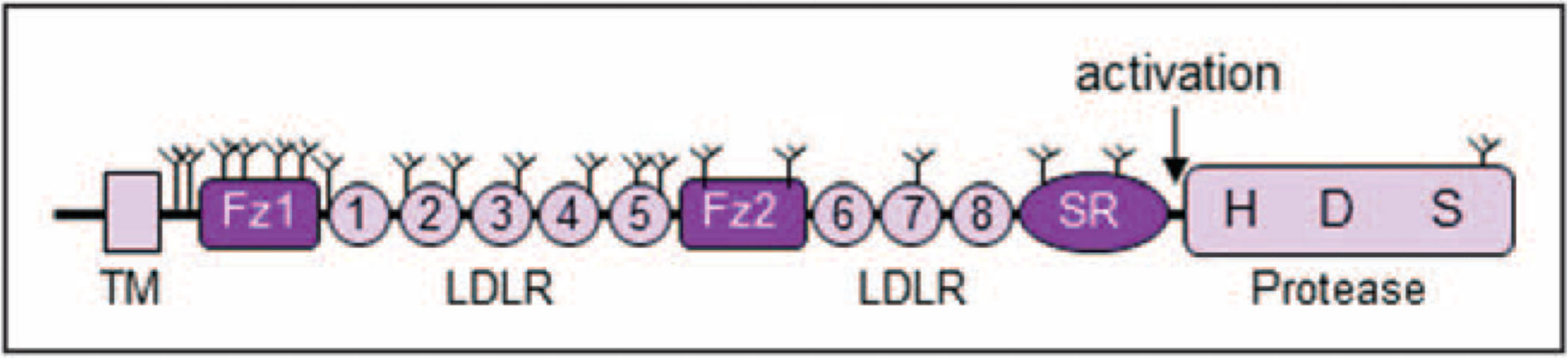

FIGURE 1.

Corin protein domain structure. Human corin consists of an $\mathrm{N}$-terminal cytoplasmic tail, a transmembrane domain (TM), and an extracellular region that contains two frizzled (Fz) domains, eight LDL receptor (LDLR) repeats, a scavenger receptor (SR) domain, and a Cterminal serine protease domain. The catalytic residues His (H), Asp (D), and Ser (S) are shown. The activation cleavage site is located between the scavenger receptor domain and the protease domain. The predicted $\mathrm{N}$-glycosylation sites are indicated by $\mathrm{Y}$ shaped symbols. 


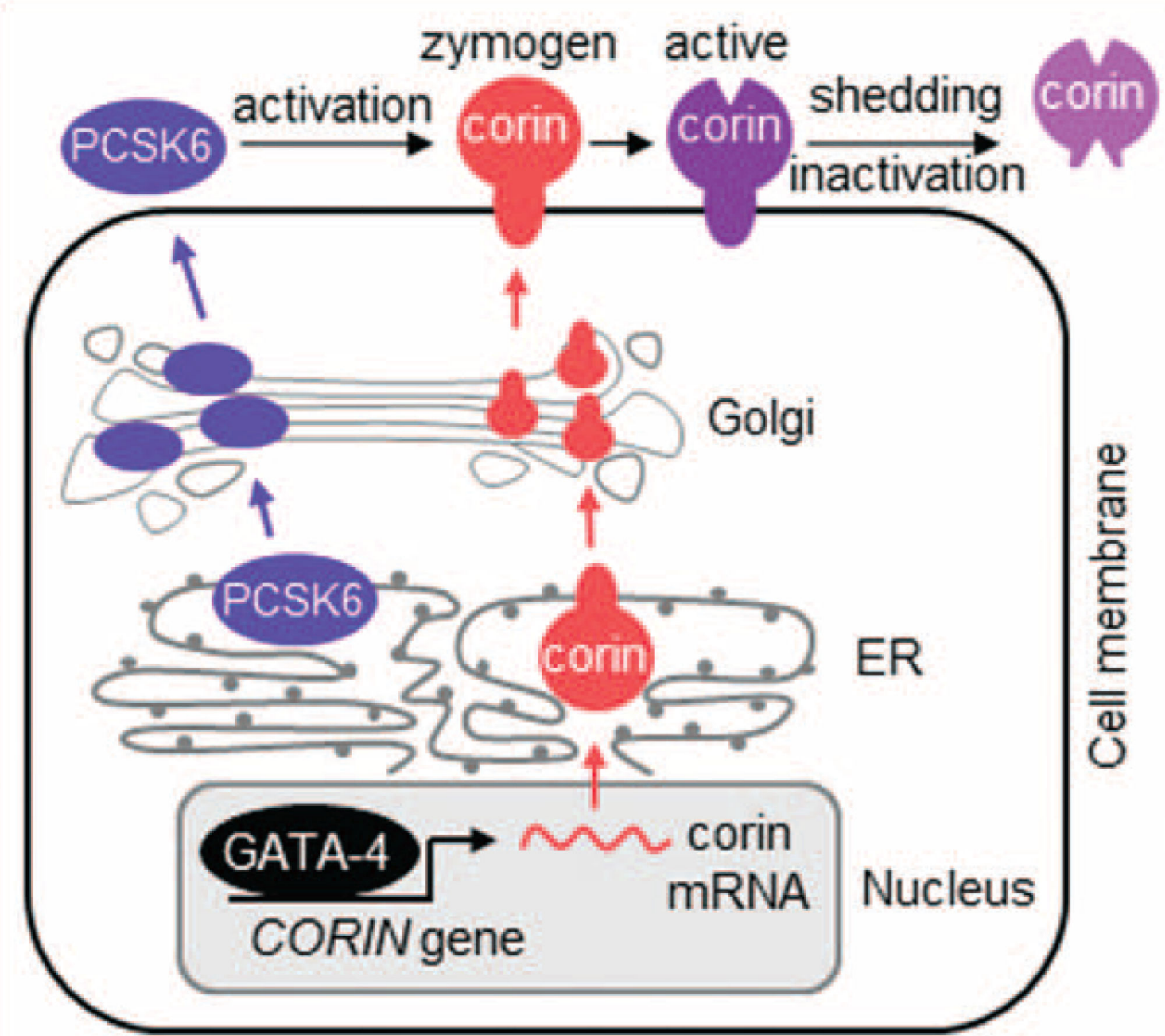

FIGURE 2.

Corin biosynthesis, intracellular trafficking, and post-translational modifications. The transcription factor GATA-4 regulates corin expression in cardiomyocytes. Newly synthesized corin and PCSK6 travel separately to the cell surface, wherein PCSK6 converts zymogen corin to an active enzyme. Protease-mediated shedding and inactivation remove corin from the cell surface and reduce corin activity. 
c. 102_103insA K317E S472G T555I/Q568P

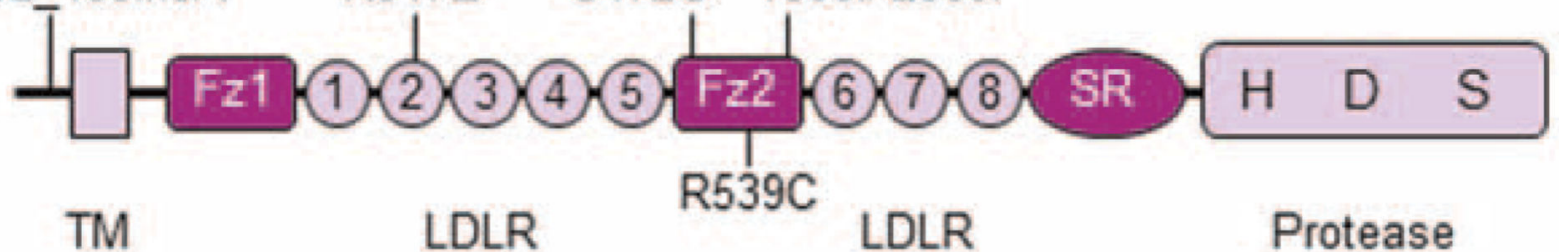

FIGURE 3.

Corin variants associated with hypertension. The locations of corin variants that have been identified in hypertensive patients are indicated. 


\section{Table 1}

Plasma and serum soluble corin levels in heart disease and stroke

\begin{tabular}{llll}
\hline Disease & Sample $(\boldsymbol{n})$ & Finding & Reference \\
\hline AMI (ST-elevation) & Plasma (50) & Correlated with myocardial necrotic markers and 4-month infarct size & {$[61]$} \\
\hline AMI & Serum (856) & Lower vs. healthy controls; inversely associated with STE/NSTEMI & {$[62 \square]$} \\
\hline AMI & Plasma (1382) & Low corin level as a predictor for MACE & {$[63 \square]$} \\
\hline CABG (with CPB) & Plasma (99) & Low corin associated with postoperative HF & {$[64]$} \\
\hline ACS (non-ST-elevation) & Serum (152) & Lower vs. healthy controls; a predictor for MACE & {$[65]$} \\
\hline CHF & Plasma (291) & Lower vs. healthy controls inversely associated with NYHA class & {$[66]$} \\
\hline ADHF & Plasma (14) & Lower vs. healthy controls & {$[67]$} \\
\hline CHF & Plasma (1148) & Low corin inversely associated with NYHA class; a predictor for MACE & {$[68 \square]$} \\
\hline Stroke & Serum (597) & Lower vs. healthy controls; a risk factor for ischemic and hemorrhagic stroke & {$[69 \square]$} \\
\hline
\end{tabular}

ACS: acute coronary syndrome; ADHF: acute decompensated heart failure; AMI: acute myocardial infarction; CABG: coronary artery bypass graft; CHF: chronic heart failure; CPB: cardiopulmonary bypass; HF: heart failure; MACE: major adverse cardiac events; $n$ : sample number; NYHA: New York Heart Association; STE/NSTEMI: ST-elevation and non-ST elevation myocardial infarction. 